\title{
Environmental controls on seasonal ecosystem evapotranspiration/ potential evapotranspiration ratio as determined by the global eddy flux measurements
}

\author{
Chunwei Liu ${ }^{1}$, Ge Sun ${ }^{2}$, Steven G. McNulty ${ }^{2}$, Asko Noormets ${ }^{3}$, and Yuan Fang ${ }^{3}$ \\ ${ }^{1}$ Jiangsu Provincial Key Laboratory of Agricultural Meteorology, College of Applied Meteorology, \\ Nanjing University of Information Science and Technology, Nanjing 210044, China \\ ${ }^{2}$ Eastern Forest Environmental Threat Assessment Center, Southern Research Station, USDA Forest Service, \\ Raleigh, NC 27606, USA \\ ${ }^{3}$ Department of Forestry and Environmental Resources, North Carolina State University, Raleigh, NC 27695, USA \\ Correspondence to: Ge Sun (gesun@ fs.fed.us)
}

Received: 15 May 2016 - Published in Hydrol. Earth Syst. Sci. Discuss.: 24 May 2016

Revised: 27 December 2016 - Accepted: 28 December 2016 - Published: 18 January 2017

\begin{abstract}
The evapotranspiration / potential evapotranspiration (AET / PET) ratio is traditionally termed as the crop coefficient $\left(K_{\mathrm{c}}\right)$ and has been generally used as ecosystem evaporative stress index. In the current hydrology literature, $K_{\mathrm{c}}$ has been widely used as a parameter to estimate crop water demand by water managers but has not been well examined for other types of ecosystems such as forests and other perennial vegetation. Understanding the seasonal dynamics of this variable for all ecosystems is important for projecting the ecohydrological responses to climate change and accurately quantifying water use at watershed to global scales. This study aimed at deriving monthly $K_{\mathrm{c}}$ for multiple vegetation cover types and understanding its environmental controls by analyzing the accumulated global eddy flux (FLUXNET) data. We examined monthly $K_{\mathrm{c}}$ data for seven vegetation covers, including open shrubland (OS), cropland (CRO), grassland (GRA), deciduous broad leaf forest (DBF), evergreen needle leaf forest (ENF), evergreen broad leaf forest (EBF), and mixed forest (MF), across 81 sites. We found that, except for evergreen forests (EBF and ENF), $K_{\mathrm{c}}$ values had large seasonal variation across all land covers. The spatial variability of $K_{\mathrm{c}}$ was well explained by latitude, suggesting site factors are a major control on $K_{\mathrm{c}}$. Seasonally, $K_{\mathrm{c}}$ increased significantly with precipitation in the summer months, except in EBF. Moreover, leaf area index (LAI) significantly influenced monthly $K_{\mathrm{c}}$ in all land covers, except in EBF. During the peak growing season, forests had the high-
\end{abstract}

est $K_{\mathrm{c}}$ values, while croplands (CRO) had the lowest. We developed a series of multivariate linear monthly regression models for $K_{\mathrm{c}}$ by land cover type and season using LAI, site latitude, and monthly precipitation as independent variables. The $K_{\mathrm{c}}$ models are useful for understanding water stress in different ecosystems under climate change and variability as well as for estimating seasonal ET for large areas with mixed land covers.

\section{Introduction}

Evapotranspiration (ET) is one of the major hydrological processes that link energy, water, and carbon cycles in terrestrial ecosystems (Sun et al., 2010, 2011a, b; Fang et al., 2015). In contrast to potential ET (PET), which depends only on atmospheric water demand (Lu et al., 2005), actual evapotranspiration (AET) is arguably the most uncertain ecohydrologic variable for quantifying watershed water budgets (Baldocchi and Ryu, 2011; Fang et al., 2015; Hao et al., 2015a) and for understanding the ecological impacts of climate and land use change (Budyko, 1974; Hao et al., 2015b), and climate variability (Hao et al., 2014). In recent years, one of the most important research questions of ecohydrology focused on how ecosystem dynamics, precipitation, AET, and PET interact in different ecosystems at seasonal and longterm scales under a changing environment (Vose et al., 2011). 
The ratio of AET to PET is traditionally termed as crop coefficient $\left(K_{\mathrm{c}}\right)$, and has been widely used to as a parameter to estimate crop water demand by water managers (Allen and Pereira, 2009; Irmak et al., 2013a). However, this parameter has not been well examined for other ecosystems (Zhou et al., 2010; Zhang et al., 2012). The ratio of AET to PET has also been used as an indicator of regional terrestrial water availability, wetness or drought index, and plant water stress (Anderson et al., 2012; Mu et al., 2012). When the annual AET / PET ratio is close to 1.0, the soil water meets ecosystem water use demand. The ratio of AET / PET or water stress level can be drastically different among different ecosystems in different environmental conditions, because AET is mainly controlled by climate (precipitation and PET) (Zhang et al., 2001; Jaramillo et al., 2013) and ecosystem species composition and structure (i.e., leaf area index, rooting depth) (Sun et al., 2011a; Hasper et al., 2016). The same seasonal PET values for a particular region are generally stable among different years (Lu et al., 2005; Rao et al., 2011), and deviation of AET / PET from the norm indicates variability in AET, which responds to precipitation and water availability when PET is stable (Rao et al., 2011). However, under a changing climate, the monthly AET / PET patterns can be rather complex since both AET and PET are affected by air temperature and precipitation (Sun et al., 2015a, b) and corresponding changes in ecosystem characteristics (e.g., plant species shift) (Donohue et al., 2007; Vose et al., 2011; Sun et al., 2014).

In the agricultural water management community, the crop coefficient method remains a popular one for approximating crop water use, despite recent advances in direct ET measurement methods (Allen et al., 1998; Baldocchi et al., 2001; Allen and Pereira, 2009; Fang et al., 2015). The $K_{\mathrm{c}}$ is termed a single-crop coefficient (Allen et al., 2006; Tabari et al., 2013) which is affected by growing periods, crop species, canopy conductance, and soil evaporation in the field scale (Shukla et al., 2014b; Ding et al., 2015). Moreover, $K_{\mathrm{c}}$ can be influenced by soil characteristics, vegetative soil cover, height, plant species distribution, and leaf area index in a larger spatial scale (Descheemaeker et al., 2011; Anda et al., 2014; Consoli and Vanella, 2014). Although the Food and Agriculture Organization of the United Nations (FAO) provides various guidelines for several crops (Allen et al., 1998), local measurements are still required to estimate $K_{\mathrm{c}}$ to account for local crop varieties and for year-to-year variation in weather conditions (Pereira et al., 2015).

Although the $K_{\mathrm{c}}$ method has been widely used for estimating AET for crops, it has not been widely used for natural ecosystems for the purpose of estimating AET due to limited continuous measurements in these systems (Zhang et al., 2001). However, as discussed earlier, ecologists and hydrologists have started to use $K_{\mathrm{c}}$ to quantify ecosystem stress and have considered $K_{\mathrm{c}}$ as a variable rather than a constant. Past studies found that $K_{\mathrm{c}}$ was influenced by the growing stages and leaf area index for maize (Kang et al., 2003; Ding et al.,
2015), winter wheat (Allen et al., 1998; Kang et al., 2003), watermelon (Shukla et al., 2014b), and fruit trees (Marsal et al., 2014b; Taylor et al., 2015). The $K_{\mathrm{c}}$ values are tabulated for each and every growth stage for many more crops all over the world (Allen et al., 1998). Variations of mid-season crop coefficients for a mixed riparian vegetation dominated by common reed (Phragmites australis) could be predicted by growing degree days in central Nebraska, USA (Irmak et al., 2013a). $K_{\mathrm{c}}$ ranged from 0.50 to 0.85 for small, open-grown shrubs, and from 0.85 to 0.95 for well-developed shrubland. The $K_{\mathrm{c}}$ values had a close logarithmic relationship with the canopy cover fraction in the highlands of northern Ethiopia (Descheemaeker et al., 2011). Overall, the nonagricultural ecosystems, such as forests, grasslands and shrublands, are heterogeneous in nature and have high soil water variability. Thus, $K_{\mathrm{c}}$ values for natural ecosystems have high variability (Allen and Pereira, 2009; Allen et al., 2011).

Therefore, the goal of this study was to explore how $K_{\mathrm{c}}$ varies among multiple ecosystems with various vegetation types over multiple seasons. Another goal was to determine the key biophysical and environmental factors such as latitude, precipitation, and leaf area index that could be used to estimate $K_{\mathrm{c}}$, and if $K_{\mathrm{c}}$ can be modeled with a reasonable accuracy at a larger spatial scale. We examined the $K_{\mathrm{c}}$ variations for seven land cover types by analyzing the FLUXNET eddy flux data (Baldocchi et al., 2001; Fang et al., 2015). Specifically, our objectives were to (1) understand the variation of monthly $K_{\mathrm{c}}$ for seven distinct land covers by analyzing the influences of environmental factors (e.g., precipitation, site latitude) on $K_{\mathrm{c}}$ and (2) to develop simple land-cover-specific regression models for estimating $K_{\mathrm{c}}$ with key environmental factors as independent variables. Specifically, we developed quantitative relationships between environmental factors and $K_{\mathrm{c}}$ by land cover types using data from FLUXNET sites for 8 croplands (CRO), 13 deciduous broad leaf forests (DBF), 5 evergreen broad leaf forests (EBF), 34 evergreen needle leaf forests (ENF), 9 grasslands (GRA), 10 mixed forests (MF), and 2 open shrublands (OS). In-depth understanding of the biophysical controls on $K_{\mathrm{c}}$ for different ecosystems is important for accurately estimating AET and anticipating the impacts of climate change on ecosystem water stress and water balances.

\section{Methods}

This synthesis study used the LaThuile eddy flux dataset that was developed by FLUXNET (http://fluxnet.ornl.gov/; Fig. 1), a global network that measures the exchanges of carbon dioxide, water vapor, and energy between the biosphere and atmosphere (Baldocchi et al., 2001). The FLUXNET data (Baldocchi et al., 2001; Baldocchi and Ryu, 2011) have been widely used to understand the evapotranspiration processes and trend (Jung et al., 2010; Fang et al., 2015), develop AET and ecosystem models (Sun et al., 2011b; Zhang 


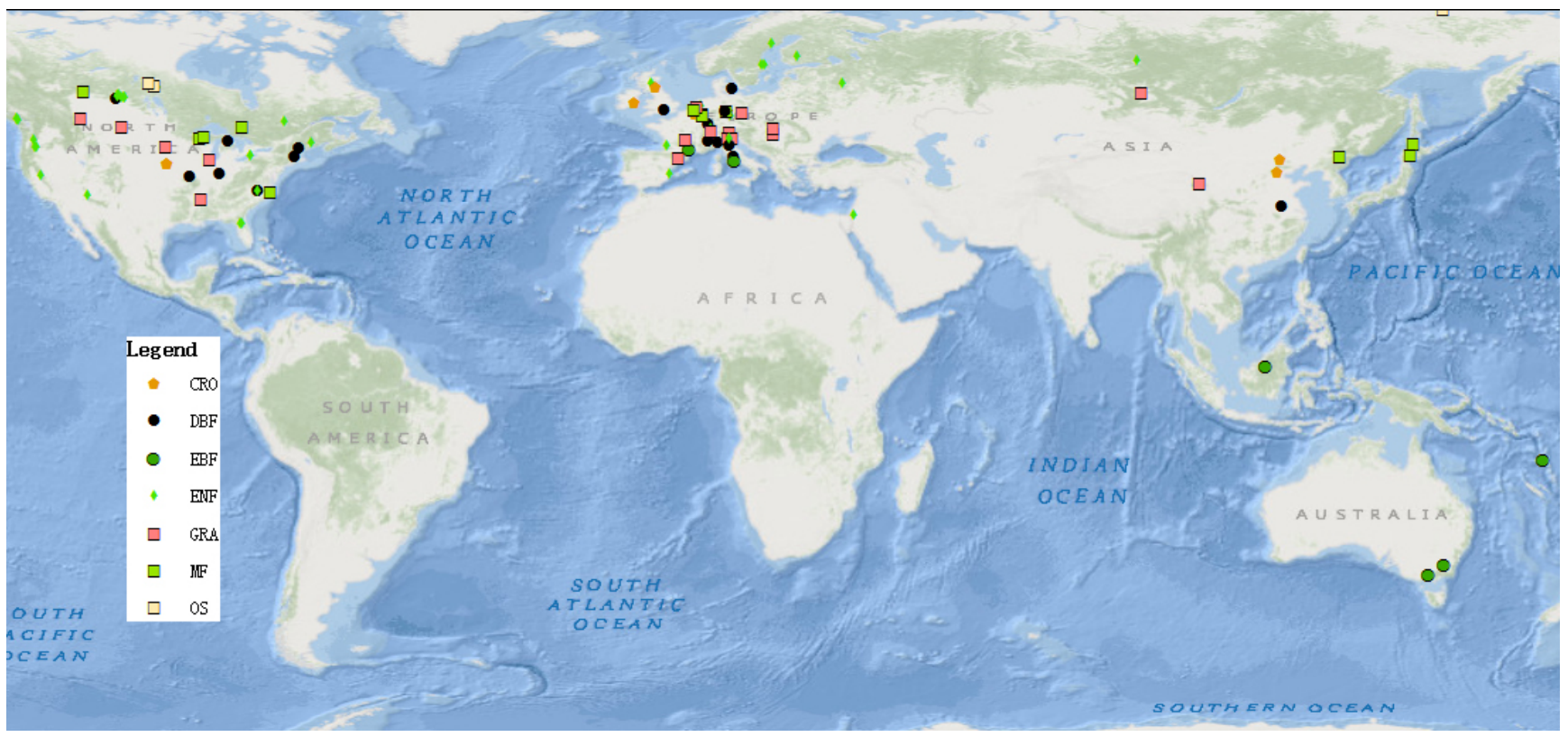

Figure 1. Location of eddy flux sites from which climate and evapotranspiration data are collected.

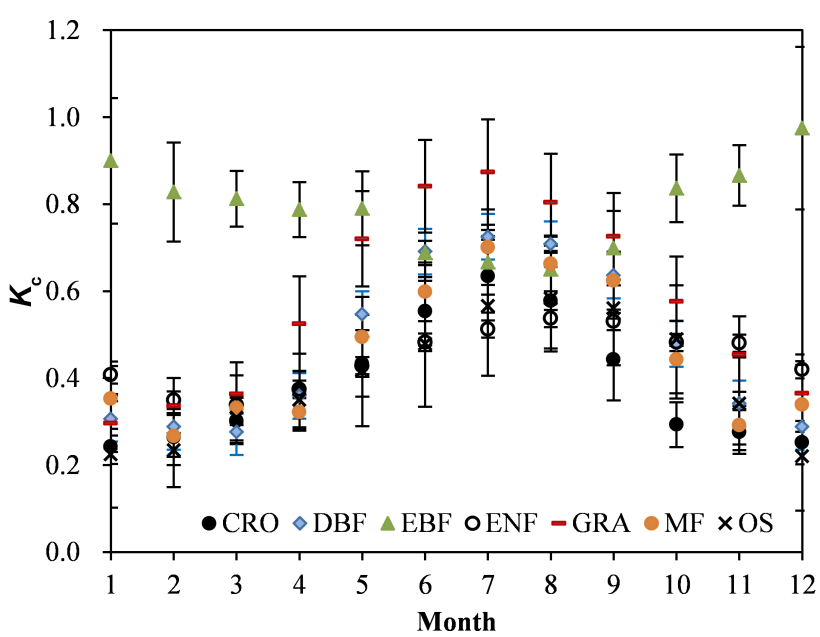

Figure 2. The variation of $K_{\mathrm{c}}$ for the different IGBP codes. The error bars are standard errors among different sites. The seven vegetation covers are open shrubland (OS), cropland (CRO), grassland (GRA), deciduous broad leaf forest (DBF), evergreen needle leaf forest $(\mathrm{ENF})$, evergreen broad leaf forest $(\mathrm{EBF})$, and mixed forest (MF). For sites in the Southern Hemisphere, July data were plotted as in January.

et al., 2016), and map continental-scale ecosystem productivity (Xiao et al., 2014; Zhang et al., 2016).

We used an existing database that was developed from the eddy flux measurements from 111 sites (Fang et al., 2015). A total of 81 sites were selected to calculate monthly $K_{\mathrm{c}}$ for multiple years and develop $K_{\mathrm{c}}$ models for different ecosystems, and 30 sites with 1 or 2 years of data were used for vali- dating the models. According to the International GeosphereBiosphere Program (IGBP) land cover classification system, these eddy flux sites represent seven land cover types: open shrubland (OS), cropland (CRO), grassland (GRA), deciduous broad leaf forest (DBF), evergreen needle leaf forest $(\mathrm{ENF})$, evergreen broad leaf forest $(\mathrm{EBF})$, and mixed forest (MF). For each eddy flux tower site (Fig. 1), we acquired AET and associated micrometeorological data, such as vapor pressure deficit, precipitation $(P)$, winds speed, and net radiation at a daily timescale during 2000-2006. Based on the hypothesis that the soil surface closely maintains a uniform height, as it is actively growing grass and completely shading the ground, PET was calculated by the FAO PenmanMonteith equation as follows (Allen et al., 1998):

$\mathrm{PET}=\frac{0.408 \Delta\left(R_{\mathrm{n}}-G\right)+\gamma \frac{900}{T+273} u_{2}\left(e_{\mathrm{s}}-e_{\mathrm{a}}\right)}{\Delta+\gamma\left(1+0.34 u_{2}\right)}$,

where $R_{\mathrm{n}}$ is net radiation at the cover surface $\left(\mathrm{MJ} \mathrm{m}^{-2} \mathrm{~d}^{-1}\right)$, $G$ is soil heat flux $\left(\mathrm{MJ} \mathrm{m}^{-2} \mathrm{~d}^{-1}\right), T$ is mean air temperature $\left({ }^{\circ} \mathrm{C}\right), u_{2}$ is wind speed $\left(\mathrm{m} \mathrm{s}^{-1}\right), e_{\mathrm{s}}$ is saturation vapor pressure $\left(\mathrm{kP}_{\mathrm{a}}\right), e_{\mathrm{a}}$ is actual vapor pressure $\left(\mathrm{kP}_{\mathrm{a}}\right), e_{\mathrm{s}}-e_{\mathrm{a}}$ is the saturation vapor pressure deficit $\left(\mathrm{kP}_{\mathrm{a}}\right), \Delta$ is slope of saturation vapor pressure curve $\left(\mathrm{kP}_{\mathrm{a}}{ }^{\circ} \mathrm{C}^{-1}\right)$, and $\gamma$ is the psychrometric constant $\left(\mathrm{kP}_{\mathrm{a}}{ }^{\circ} \mathrm{C}^{-1}\right)$. Most sites are in the Northern Hemisphere, except three EBF sites.

The monthly $K_{\mathrm{c}}$, which is defined as the ratio of the measured total monthly AET and the total monthly PET calculated by Eq. (1), varies by month and vegetation types (Eq. 2). The average annual $K_{\mathrm{c}}$ values were calculated by averaging monthly $K_{\mathrm{c}}$ from January to December for each 


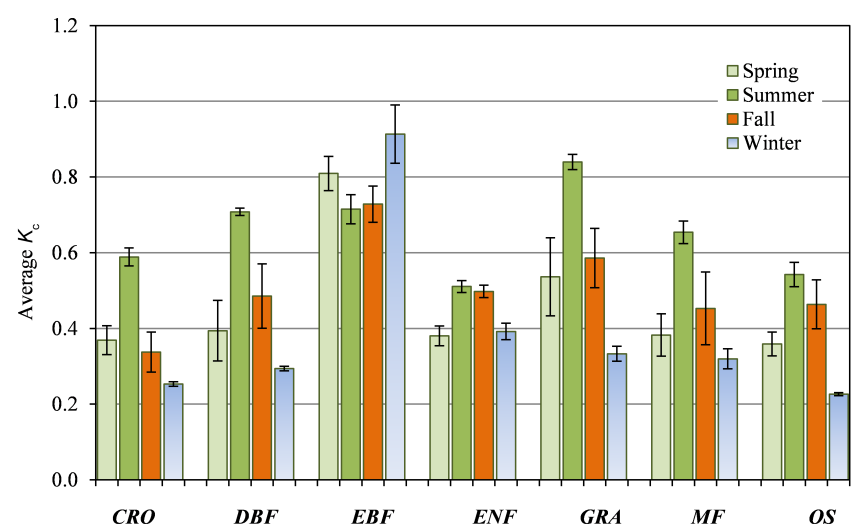

Figure 3. Average $K_{\mathrm{c}}$ in spring, summer, fall, and winter in different vegetation types. The error bars are standard errors among different sites. Spring is the months of February, March, and April; summer is May, June, and July; fall is August, September, and October; winter is November, December, and January. In the Southern Hemisphere, spring is August, September, and October; summer is November, December, and January; fall is February, March, and April; and winter is May, June, and July.

site.

$K_{\mathrm{c}}=\frac{\mathrm{AET}}{\mathrm{PET}}$

The leaf area index (LAI) time series data for each tower site were downloaded from the Oak Ridge National Laboratory Distributed Active Archive Center (http://daac.ornl.gov/ cgi-bin/MODIS/GR_col5_1/mod_viz.html). Moderate Resolution Imaging Spectroradiometer (MODIS) LAI data were derived from the fraction of absorbed photosynthetically active radiation (FPAR) that a plant canopy absorbs for photosynthesis and growth in the $0.4-0.7 \mathrm{~nm}$ spectral range. The MODIS LAI/FPAR algorithm exploits the spectral information of MODIS surface reflectance at up to seven spectral bands. We extracted monthly LAI data for the periods from 2000 to 2006 across 111 sites using 8-day GeoTIFF data from the MODIS land subsets' $1 \mathrm{~km}$ LAI global fields. We estimated monthly LAI for each flux tower by computing the mean of the 8-day daily values for each month (Fang et al., 2015).

\section{Results}

\subsection{Seasonal variations and long-term means of $K_{\mathfrak{c}}$ by land cover}

The average monthly $K_{\mathrm{c}}$ based on eddy flux data from 2000 to 2007 increased gradually from January to July and then decreased (Fig. 2). Evergreen broad leaf forest (EBF) had the highest mean monthly $K_{\mathrm{c}}(0.97 \pm 0.19)$ (mean \pm standard error) in December (June for sites in the Southern Hemisphere). $K_{\mathrm{c}}$ for both EBF and ENF varied less seasonally
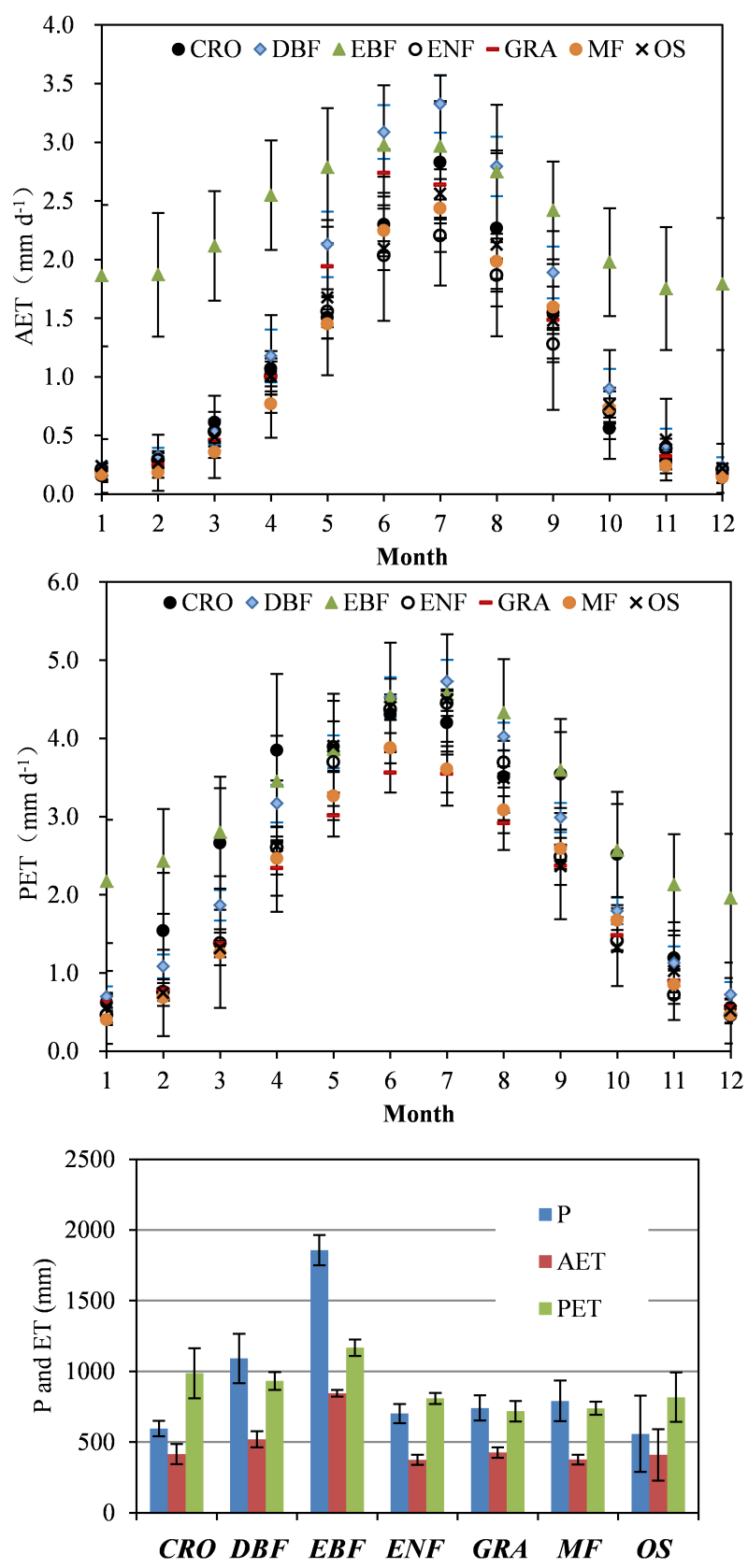

Figure 4. Monthly AET and PET, and annual total precipitation $(P)$, AET, and PET for different vegetation types. The error bars are standard errors among different sites.

than other forest types (Fig. 2). Standard errors for grassland (GRA), evergreen needle leaf forest (ENF), and open shrubland (OS) (0.10-0.17) were larger than for other land cover types (0.03-0.10) for April to August. EBF had higher $K_{\mathrm{c}}$ for all seasons than other land covers with a peak value of $0.91( \pm 0.08)$ in the winter season (Fig. 3). In winter seasons, cropland (CRO) and OS had the lowest $K_{\mathrm{c}}: 0.25( \pm 0.006)$ and $0.22( \pm 0.004)$, respectively. 

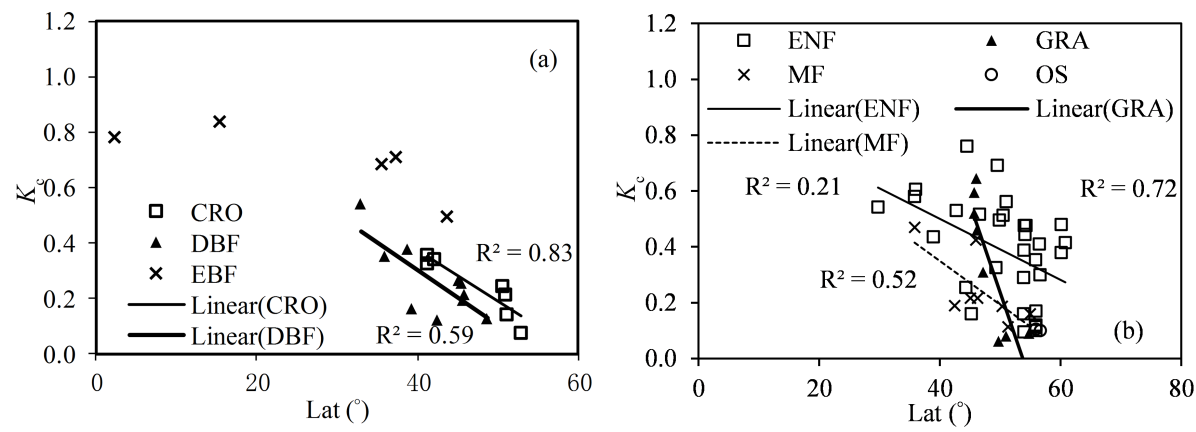

Figure 5. Variation of annual $K_{\mathrm{c}}$ at different latitudes (lat): (a) cropland (CRO), deciduous broad leaf forest (DBF), and evergreen broad leaf forest (EBF); (b) evergreen needle leaf forest (ENF), grassland (GRA), mixed forest (MF), and open shrubland (OS). The absolute values of the latitude were used in EBF for sites in the Southern Hemisphere, and all the determination coefficients $\left(R^{2}\right)$ listed in the figure were significant $(p<0.05)$.

The mean annual $K_{\mathrm{c}}$ was $0.39( \pm 0.04), 0.47( \pm 0.05)$, $0.75( \pm 0.03), 0.45( \pm 0.02), 0.57( \pm 0.06), 0.45( \pm 0.05)$, and $0.40( \pm 0.04)$ for CRO, DBF, EBF, ENF, GRA, $\mathrm{MF}$, and OS, respectively. Yearly average precipitation was higher in EBF and DBF than other land covers (Fig. 4). The precipitation ranking by land cover type was $\mathrm{EBF}>\mathrm{DBF}>\mathrm{MF}>\mathrm{GRA}>\mathrm{ENF}>\mathrm{CRO}>\mathrm{OS}$. Consequently, OS, MF, GRA, CRO, and ENF had relatively lower yearly AET (376-425 mm) than EBF and DBF. Moreover, DBF, EBF, and CRO had higher PET than other vegetation surfaces. The variations for monthly AET and PET were presented in Fig. 4 to the contrasting patterns of these two variables. The AET and PET reached maximum values 2.2-3.3 and $3.6-4.7 \mathrm{~mm} \mathrm{~d}^{-1}$ in June or July (December or January for the Southern Hemisphere), respectively.

\subsection{Environmental controls on $K_{\mathrm{c}}$}

As indicated in Eq. (1), factors such as temperature and solar radiation were used for PET calculations, and were not independent of $K_{\mathrm{c}}$. Therefore, we chose other independent factors to simulate $K_{\mathrm{c}}$. Site latitude is a readily available variable for a particular location, but is crucial to the day length and incoming radiation over the year.

The results showed that annual $K_{\mathrm{c}}$ was negatively $(p<0.05)$ correlated with latitude (Fig. 5) for CRO, DBF, ENF, GRA, and MF with a determination coefficient $\left(R^{2}\right)$ of $0.83,0.59,0.21,0.72$, and 0.52 , respectively. For OS, annual mean $K_{\mathrm{c}}$ also decreased with the increase in site latitude. Most of the study site fell between 30 and $60^{\circ} \mathrm{N}$ in latitude.

At the seasonal scale, the linear relationships between monthly $K_{\mathrm{c}}$ and total monthly precipitation differed among different land cover types (Fig. 6). Monthly $K_{\mathrm{c}}$ increased with monthly precipitation in the same ecosystem type with the $R^{2}$ ranking from high to low: OS $>$ MF $>$ GRA $>$ ENF $>$ CRO $>$ DBF. The monthly $K_{\mathrm{c}}$ for OS was especially sensitive to precipitation $\left(R^{2}=0.69\right.$, $p<0.001)$. The monthly $K_{\mathrm{c}}$ for EBF was not as sensitive to precipitation as other ecosystems because EBF was generally found in a wet environment with a peak monthly precipitation of $468 \mathrm{~mm}$. Moreover, $K_{\mathrm{c}}$ for OS, GRA, and MF in relatively drier environments had lower values (Fig. 2). Therefore, $K_{\mathrm{c}}$ was closely related to the monthly precipitation.

In addition to growing season, site latitude, and monthly precipitation, leaf area index also affected the monthly $K_{\mathrm{c}}$ (Fig. 7). $K_{\mathrm{c}}$ was obviously influenced by LAI for all land covers except EBF. The determination coefficients for different land covers were $\mathrm{OS}>\mathrm{MF}=\mathrm{GRA}>\mathrm{ENF}>\mathrm{DBF}>\mathrm{CRO}$. The LAI range was up to $6 \mathrm{~m}^{2} \mathrm{~m}^{-2}$ in most land covers, while it only reached $3-4 \mathrm{~m}^{2} \mathrm{~m}^{-2}$ in OS and CRO.

\section{$3.3 \quad K_{\mathrm{c}}$ models}

A series of empirical $K_{\mathrm{c}}$ models have been developed using a multiple linear regression approach with precipitation, LAI, and site latitude as independent variables (Table 1). The monthly precipitation, LAI, and site latitude influence $K_{\mathrm{c}}(p<0.1)$ for most ecosystems studied in different seasons except at EBF in summer and fall, and for OS in the spring. As annual precipitation increases, total leaf area increases; therefore, $K_{\mathrm{c}}$ increases for ENF in all seasons and most of the time for DBF and MF. As site latitude increases, $K_{\mathrm{c}}$ values are found to decrease in some periods at CRO, DBF, and MF sites. In addition, $K_{\mathrm{c}}$ is closely correlated to LAI, site latitude, and monthly precipitation at ENF in fall and OS in winter with an $R^{2}$ of 0.55 and 0.99 , respectively. All land covers have peak values $(0.53 \pm 0.04-1.01 \pm 0.17)$ in the summer months. Except for EBF and GRA, $K_{\mathrm{c}}$ values have a close relationship with the monthly precipitation in the summer with $R^{2}$ ranging from 0.21 to 0.90 . The linear relationships are significant for most vegetation types, suggesting that the regression models (Table 1) can be used to estimate monthly $K_{\mathrm{c}}$ if LAI and precipitation for a specific ecosystem are available. 
Table 1. Multiple linear regression relationships among crop coefficient and LAI, precipitation, and site latitude in different seasons.

\begin{tabular}{|c|c|c|c|c|c|c|c|c|}
\hline IGBP & Season & $N$ & $R^{2}$ & $K_{\mathrm{c}}$ & $b$ & $a_{1}$ & $a_{2}$ & $a_{3}$ \\
\hline \multirow[t]{4}{*}{$\mathrm{CRO}$} & Spring & 24 & 0.16 & 0.31 & $0.242^{* * *}$ & $0.141^{*}$ & & \\
\hline & Summer & 24 & 0.21 & 0.57 & $0.331^{* *}$ & & & $0.0033^{*}$ \\
\hline & Fall & 23 & 0.78 & 0.48 & 0.036 & $0.472^{* * *}$ & & \\
\hline & Winter & 21 & 0.36 & 0.26 & $0.920^{* * *}$ & & $-0.0141^{* *}$ & \\
\hline \multirow[t]{4}{*}{$\mathrm{DBF}$} & Spring & 39 & 0.49 & 0.30 & $0.479^{* *}$ & & $-0.0076^{*}$ & $0.0022^{* * *}$ \\
\hline & Summer & 39 & 0.42 & 0.65 & $0.536^{* * *}$ & & & $0.0011^{* * *}$ \\
\hline & Fall & 39 & 0.13 & 0.60 & $0.462^{* * *}$ & & & $0.0014^{*}$ \\
\hline & Winter & 39 & 0.15 & 0.30 & $0.713^{* * *}$ & & $-0.0094^{*}$ & \\
\hline \multirow[t]{4}{*}{$\mathrm{EBF}$} & Spring & 15 & 0.25 & 0.74 & $0.875^{* * *}$ & & $-0.0050^{*}$ & \\
\hline & Summer & 15 & - & 0.91 & $0.911^{* * *}$ & & & \\
\hline & Fall & 15 & - & 0.80 & $0.798^{* * *}$ & & & \\
\hline & Winter & 15 & 0.42 & 0.72 & $0.676^{* * *}$ & $0.050^{*}$ & $-0.0050^{* *}$ & \\
\hline \multirow[t]{4}{*}{ ENF } & Spring & 96 & 0.39 & 0.37 & $0.225^{* * *}$ & $0.060^{* * *}$ & & $0.0017^{* * *}$ \\
\hline & Summer & 99 & 0.59 & 0.49 & $0.211^{* * *}$ & $0.053^{* * *}$ & & $0.0020^{* * *}$ \\
\hline & Fall & 98 & 0.55 & 0.52 & -0.040 & $0.066^{* * *}$ & $0.0049^{*}$ & $0.0025^{* * *}$ \\
\hline & Winter & 92 & 0.21 & 0.44 & $0.293^{* * *}$ & $0.084^{*}$ & & $0.0010^{*}$ \\
\hline \multirow[t]{4}{*}{ GRA } & Spring & 27 & 0.48 & 0.45 & $0.237^{* * *}$ & & & $0.0052^{* * *}$ \\
\hline & Summer & 27 & 0.23 & 0.86 & $0.572^{* * *}$ & $0.110^{*}$ & & \\
\hline & Fall & 27 & 0.30 & 0.76 & $0.499^{* * *}$ & $0.123^{* *}$ & & \\
\hline & Winter & 27 & 0.26 & 0.41 & $0.256^{* *}$ & & & $0.0038^{* *}$ \\
\hline \multirow[t]{4}{*}{ MF } & Spring & 30 & 0.67 & 0.31 & $0.099^{* *}$ & $0.188^{* * *}$ & & $0.0012^{* * *}$ \\
\hline & Summer & 30 & 0.40 & 0.61 & $0.372^{* * *}$ & & & $0.0029^{* * *}$ \\
\hline & Fall & 30 & 0.54 & 0.58 & $0.250^{* * *}$ & $0.071^{* * *}$ & & $0.0018^{* * *}$ \\
\hline & Winter & 30 & 0.13 & 0.33 & $0.961^{* *}$ & & $-0.0136^{*}$ & \\
\hline \multirow[t]{4}{*}{ OS } & Spring & 6 & - & 0.23 & $0.230^{* * *}$ & & & \\
\hline & Summer & 6 & 0.90 & 0.35 & $-5.419^{*}$ & & $0.1005^{*}$ & $0.0026^{*}$ \\
\hline & Fall & 6 & 0.88 & 0.42 & $-9.921^{*}$ & $0.051^{*}$ & $0.1828^{*}$ & \\
\hline & Winter & 6 & 0.99 & 0.14 & $-4.919^{*}$ & $0.629^{*}$ & $0.0882^{*}$ & $0.0032 *$ \\
\hline
\end{tabular}

Note: $N$ is the number of observations used, $R^{2}$ the determination coefficient, $K_{\mathrm{c}}$ is the average $K_{\mathrm{c}}$ for seasons. $b$ is the intercept of the multiple linear equation, $a_{1}$ the coefficient of LAI, $a_{2}$ the coefficient of site latitude (absolute values), $a_{3}$ the coefficient of precipitation. IGBP is the International Geosphere-Biosphere Program land cover classification system: cropland (CRO), deciduous broad leaf forest (DBF), evergreen broad leaf forest (EBF), evergreen needle leaf forest (ENF), grassland (GRA), mixed forest (MF), and open shrubland (OS). ${ }^{* * *},{ }^{* *},{ }^{*}$ stand for $p<0.001, p<0.01, p<0.1$ and the blank spaces indicate nonsignificant values. In the Northern Hemisphere, spring is the months of February, March, and April; summer is May, June, and July; fall is August, September, and October; winter is November, December, and January. In the Southern Hemisphere, spring is August, September, and October; summer is November, December, and January; fall is February, March, and April; and winter is May, June, and July.

\subsection{The validation of the regression models of $K_{\mathrm{c}}$}

All $K_{\mathrm{c}}$ multiple regression models for different seasons were validated by ecosystem type (Fig. 8). The model validation was carried out for 30 sites at a monthly scale. The results showed that the modeled AET calculated from the multiple $K_{\mathrm{c}}$ models compared well to measurements with $R^{2}$ ranging 0.28-0.56. Among the ecosystems, the model for DBF appeared to be the most accurate one, with an $R^{2}$ of 0.56 . However, model validation results for $\mathrm{CRO}, \mathrm{EBF}$, and OS were not as satisfactory as indicated by the slopes $(<1.0$ or $>1.0$ ) of the regression equations.

\section{Discussion}

Our study estimated annual and seasonal crop coefficient $\left(K_{\mathrm{c}}\right)$ for seven land cover types using measured global eddy flux data. We comprehensively evaluated environmental controls (i.e., precipitation, LAI, and site latitude) on annual and growing season $K_{\mathrm{c}}$ and developed a series of multiple linear regression models that can be used for estimating monthly AET over time and space for some vegetation types.

\subsection{Crop coefficient variation in different seasons}

Several recent studies had shown that $K_{\mathrm{c}}$ reached the maximum value in the middle of the growing season in many 

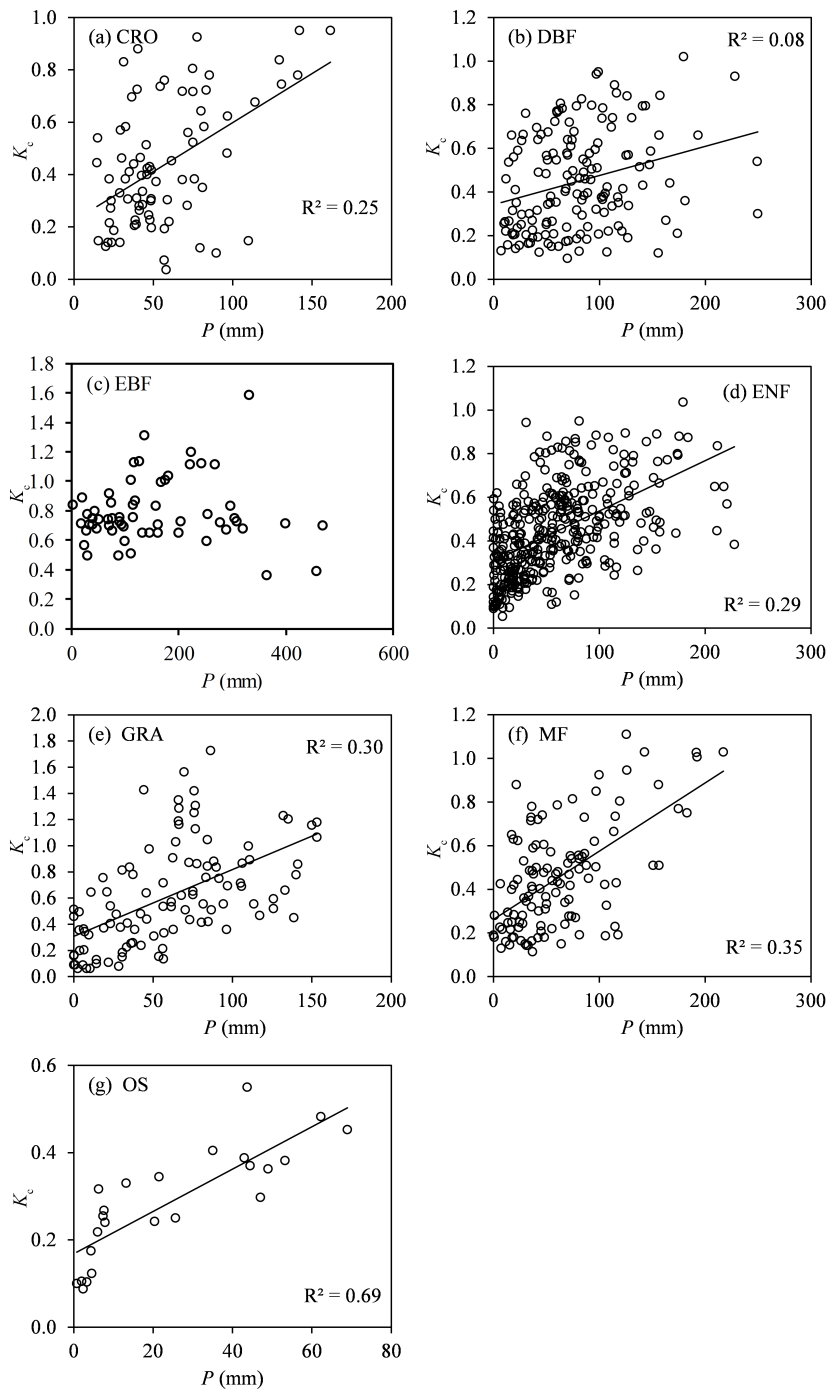

Figure 6. Relationships between the average monthly $K_{\mathrm{c}}$ and monthly precipitation $(P, \mathrm{~mm})$ for different vegetation surfaces. Panels (a-g) represent cropland (CRO), deciduous broad leaf forest (DBF), evergreen broad leaf forest (EBF), evergreen needle leaf forest (ENF), grassland (GRA), mixed forest (MF), and open shrubland (OS), respectively. All the determination coefficients $\left(R^{2}\right)$ listed in the figure were significant $(p<0.001)$.

ecosystems, such as a P. euphratica forest in the riparian area (Hou et al., 2010) in a desert environment, a watermelon crop covered with plastic mulch in Florida (Shukla et al., 2014a, b), soybean in Nebraska (Irmak et al., 2013b), and a temperate desert steppe in Inner Mongolia (Zhang et al., 2012). As Fig. 2 shows, most of the land covers have peak $K_{\mathrm{c}}$ during June to August (in the Northern Hemisphere), while the seasonal patterns of ENF and EBF vary less than other surfaces. Vegetation growth for both the ENF and EBF sites is active throughout the year. The mean crop coefficient for mediumdensity fruit trees in the early growing season is about 0.5 (Allen et al., 1998; Allen and Pereira, 2009), which is simi-
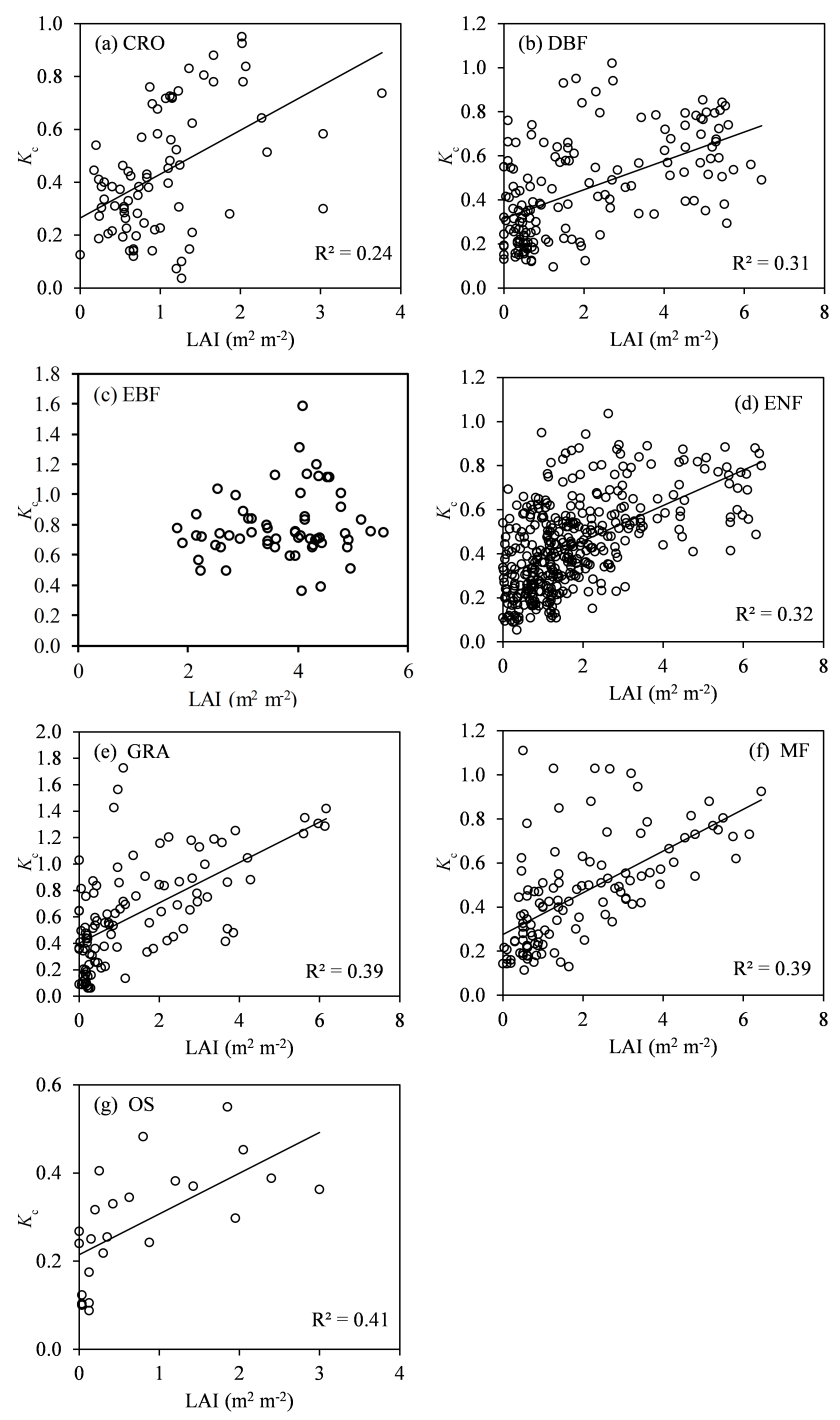

Figure 7. Relationships between the average monthly $K_{\mathrm{c}}$ and leaf area index for different vegetation surfaces. Panels (a-g) stand for cropland (CRO), deciduous broad leaf forest (DBF), evergreen broad leaf forest (EBF), evergreen needle leaf forest (ENF), grassland (GRA), mixed forest (MF), and open shrubland (OS). All the determination coefficients $\left(R^{2}\right)$ listed in the figure were significant $(p<0.05)$.

lar to those found for DBF or MF during April and May. In addition, the middle season $K_{\mathrm{c}}$ values for apple and peach trees with active ground cover were higher than $K_{\mathrm{c}}$ for DBF sites during the summer. It is likely that the orchards had higher evapotranspiration rates than natural forests due to irrigation. We also find that the CRO has relatively low precipitation with a high PET because of irrigation. The irrigation has been proven to be a determining factor for AET at the local and even at the global scale (Jaramillo and Destouni, 2015). Thus, the $K_{\mathrm{c}}$ for CRO mainly depends on the irrigation schedule and the primary crops. The loss of leaves on DBF and MF lead to an larger obvious standard error for 


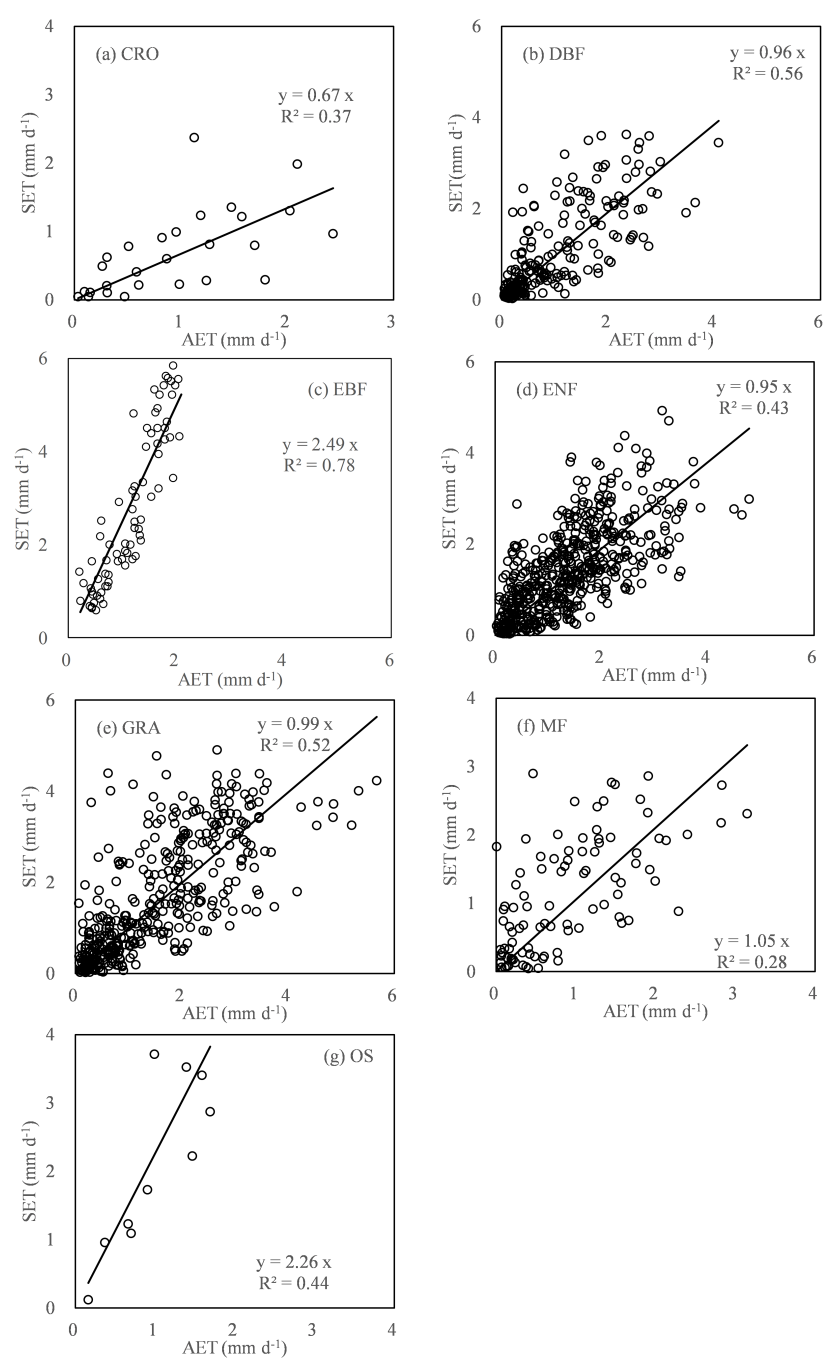

Figure 8. Relationships between the simulated ET using $K_{\mathrm{c}}$ from Table 1 (SET) and the measured ET (AET) for different vegetation surfaces. Panels (a-f) stand for cropland (CRO), deciduous broad leaf forest (DBF), evergreen broad leaf forest (EBF), evergreen needle leaf forest (ENF), grassland (GRA), mixed forest (MF), and open shrubland (OS). All the determination coefficients $\left(R^{2}\right)$ listed in the figure were significant $(p<0.001)$.

$K_{\mathrm{c}}$ in fall (Fig. 3). The soil water evaporation represents the main water loss, which is thus a key component of $K_{\mathrm{c}}$ when the ecosystems lack leaves or plants in winter (Allen et al., 1998). Moreover, the $K_{\mathrm{c}}$ is biologically meaningful in vegetation type distribution (Stephenson, 1998); thus, when LAI becomes small for DBF during winter, the $K_{\mathrm{c}}$ reflects the characteristics of evaporation capacity for the ground surface.

\subsection{Environmental control factors for $K_{\mathrm{c}}$}

The ecosystem covers and the distributions of the vegetation classes are determined by the latitude (Potter et al., 1993). Crop coefficient varies predominately by ecosystems, and $K_{\mathrm{c}}$ increases as the site latitude decreases for the same land cover type (Fig. 5). As the latitude decreases, the increasing temperature and the solar radiation results of PET are increasing; thus, the acceleration for AET should be faster than PET. The reason may be that the vegetation characteristics are different for the same land cover type in different latitudes. Models developed from the FLUXNET data may be best used on flat areas for a specific latitude given that eddy covariance towers were generally installed on flat lands (Baldocchi et al., 2001). For areas with complex topography, the relationship between $K_{\mathrm{c}}$ and site latitude may be more complicated.

Spatial variations of $K_{\mathrm{c}}$ are characteristic of ecosystems, but $K_{\mathrm{c}}$ is also affected by climate factors such as rainfall. For example, $K_{\mathrm{c}}$ was highly correlated with precipitation for most land covers (Fig. 6). The rainfall is the major source of soil water and AET in natural ecosystems (Parent and Anctil, 2012). During dry years or periods, a lack of precipitation may cause a reduction of the leaf area index, and $K_{\mathrm{c}}$ will decrease. During rainy seasons, as leaf area index and stomatal conductance of trees and rain-fed crops increases, so does $K_{\mathrm{c}}$ (Kar et al., 2006; Zeppel et al., 2008). Irrigation of cropland is a primary mechanism for increasing yield (Fereres and Soriano, 2007; Du et al., 2015), so the CRO may have a high monthly $K_{\mathrm{c}}$ even at sites with a low precipitation. In contrast, $K_{\mathrm{c}}$ does not have a close relationship with precipitation under a wet environment. For example, the EBF site had a monthly precipitation as high as $468 \mathrm{~mm} \mathrm{month}^{-1}$ and generally exceeded monthly AET. In an opposite case for the OS sites, monthly precipitation values were between 0.7 and $69 \mathrm{~mm}$, and $K_{\mathrm{c}}$ was highly correlated with monthly precipitation. Moreover, the time lag between precipitation and soil moisture might cause errors in calculating AET and modeling $K_{\mathrm{c}}$ in the long dry or wet season. However, at the monthly scale, previous modeling work (Fang et al., 2015) suggests that considering a time lag does not increase the prediction power dramatically (G. Sun, personal communication, 2015).

Besides precipitation, LAI also affects $K_{\mathrm{c}}$ in dry and semihumid areas (Kang et al., 2003; Zhang et al., 2012). Unlike precipitation, LAI directly affects $K_{\mathrm{c}}$ in AET calculations (Tolk and Howell, 2001; Novák, 2012). Interannual $K_{\mathrm{c}}$ values are stable at the GRA and OS sites due to the steady seasonal LAI between years while the plantation forest sites had a more dynamic LAI pattern (Marsal et al., 2014a). As the growth rate of the perennial plants could have large effects on the relationship between $K_{\mathrm{c}}$ and LAI, long-term data are needed to estimate $K_{\mathrm{c}}$ as a function of all environmental factors. 


\subsection{Modeling the dynamics of $K_{c}$}

Our study results are consistent with previous studies that show that the growing stage is a key factor for estimating $K_{\mathrm{c}}$ in agricultural crops (Allen et al., 1998; Zhang et al., 2013; Alberto et al., 2014; Wei et al., 2015), fruit trees (Abrisqueta et al., 2013; Marsal et al., 2014b), salt grass (Bawazir et al., 2014), and Populus euphratica Oliv. forest (Hou et al., 2010). Additionally, our study showed that $K_{\text {c }}$ fluctuated more dramatically in DBF, GRA, and MF than other land covers in different seasons (Table 1). Studies also show that monthly leaf stomatal resistance that varies over time is important in estimating the seasonal crop coefficient for a citrus orchard (Taylor et al., 2015). The LAI and total monthly precipitation were considered as independent factors (BondLamberty and Thomson, 2010) and both of them varied in both time and space while the site latitude only represented spatial influences on $K_{\mathrm{c}}$. The modeled AET was acceptable for DBF, ENF, GRA, and MF (Fig. 8), and could be used for monthly AET calculation for large-spatial-scale and homogeneous ecosystems. The slope of CRO modeling ET to AET was $50 \%$ below the $1: 1$ line which may be because the crops were irrigated when the soil lacked water content. Meanwhile, the OS having a large proportion of bare soil with low soil water content may be the result of an overestimate in modeling ET. The lack of site samples may cause a low accuracy of validation in OS and EBF modeling ET. Thus, the multiple linear regression equations developed from this study take into account both spatial and temporal changes in land surface characteristics and offer a powerful tool for estimating seasonal dynamics of $K_{\mathrm{c}}$ for most ecosystems (Table 1).

\section{Conclusions}

In seeking a convenient method to calculate monthly AET at large spatial scales, we comprehensively examined the relations between $K_{\mathrm{c}}$ and environmental factors using eddy flux data from 81 sites (mainly in the Northern Hemisphere) with different land covers. We found that $K_{\mathrm{c}}$ values varied largely among CRO, DBF, EBF, GRA, and MF, and across seasons. Besides EBF, precipitation determined $K_{\mathrm{c}}$ in the growing seasons (such as summer) and was chosen as a key variable to calculate $K_{\mathrm{c}}$. We established multiple linear equations for different land covers and seasons to model the dynamics of $K_{\mathrm{c}}$ as function of LAI, site latitude, and monthly precipitation. These empirical models could be helpful in calculating monthly AET at the regional scale with readily available climatic data and vegetation structure information. Our study extended the applications of the traditional $K_{\mathrm{c}}$ method for estimating crop water use to estimating AET rates and evaporative stress for natural ecosystems. Future studies should further test the applicability of the empirical $K_{\mathrm{c}}$ models un- der extreme climatic conditions and for those ecosystems that are underrepresented by the FLUXNET.

\section{Data availability}

The FLUXNET data are not publicly accessible; however, the data can be downloaded for free by the user at the following website: http://fluxnet.fluxdata.org/data/ la-thuile-dataset/.

Acknowledgement. We are grateful for grants from the National Natural Science Foundation of China (no. 51309132), for supporting this collaborative work between Nanjing University of Information Science and Technology and the Eastern Forest Environmental Threat Assessment Center at the USDA Forest Service Southern Research Station. This work used eddy covariance data acquired by the FLUXNET community and in particular by the following networks: AmeriFlux (US Department of Energy, Biological and Environmental Research, Terrestrial Carbon Program (DEFG02-04ER63917 and DE-FG02-04ER63911)), AfriFlux, AsiaFlux, CarboAfrica, CarboEuropeIP, CarboItaly, CarboMont, ChinaFlux, Fluxnet-Canada (supported by CFCAS, NSERC, BIOCAP, Environment Canada, and NRCan), GreenGrass, KoFlux, LBA, NECC, OzFlux, TCOS-Siberia, and the United States China Carbon Consortium (USCCC). We acknowledge the financial support to the eddy covariance data harmonization provided by CarboEuropeIP, FAO-GTOS-TCO, iLEAPS, Max Planck Institute for Biogeochemistry, National Science Foundation, University of Tuscia, Université Laval and Environment Canada, and the US Department of Energy, and the database development and technical support from Berkeley Water Center, Lawrence Berkeley National Laboratory, Microsoft Research eScience, Oak Ridge National Laboratory, University of California, Berkeley, and University of Virginia. This work also used MODIS land subset (Oak Ridge National Laboratory Distributed Active Archive Center (ORNL DAAC) 2011 MODIS subsetted land products, collection 5). We also thank the reviewers and associate editor for their constructive comments on the manuscript.

Edited by: K. Bishop

Reviewed by: three anonymous referees

\section{References}

Abrisqueta, I., Abrisqueta, J. M., Tapia, L. M., Munguía, J. P., Conejero, W., Vera, J., and Ruiz-Sánchez, M. C.: Basal crop coefficients for early-season peach trees, Agr. Water Manage., 121, 158-163, doi:10.1016/j.agwat.2013.02.001, 2013.

Alberto, M. C. R., Quilty, J. R., Buresh, R. J., Wassmann, R., Haidar, S., Correa, T. Q., and Sandro, J. M.: Actual evapotranspiration and dual crop coefficients for dry-seeded rice and hybrid maize grown with overhead sprinkler irrigation, Agr. Water Manage., 136, 1-12, doi:10.1016/j.agwat.2014.01.005, 2014.

Allen, R. G. and Pereira, L. S.: Estimating crop coefficients from fraction of ground cover and height, Irrigation Sci., 28, 17-34, doi:10.1007/s00271-009-0182-z, 2009. 
Allen, R. G., Pereira, L. S., Raes, D., and Smith, M.: Crop evapotranspiration, FAO irrigation and drainage paper, No. 56, 1998.

Allen, R. G., Pruitt, W. O., Wright, J. L., Howell, T. A., Ventura, F., Snyder, R., Itenfisu, D., Steduto, P., Berengena, J., Yrisarry, J. B., Smith, M., Pereira, L. S., Raes, D., Perrier, A., Alves, I., Walter, I., and Elliott, R.: A recommendation on standardized surface resistance for hourly calculation of reference ETo by the FAO56 Penman-Monteith method, Agr. Water Manage., 81, 122, doi:10.1016/j.agwat.2005.03.007, 2006.

Allen, R. G., Pereira, L. S., Howell, T. A., and Jensen, M. E.: Evapotranspiration information reporting: I. Factors governing measurement accuracy, Agr. Water Manage., 98, 899-920, doi:10.1016/j.agwat.2010.12.015, 2011.

Anda, A., Silva, J. A. T. D., and Soos, G.: Evapotranspiration and crop coefficient of common reed at the surroundings of Lake Balaton, Hungary, Aquat. Botany, 116, 53-59, doi:10.1016/j.aquabot.2014.01.008, 2014.

Anderson, M. C., Allen, R. G., Morse, A., and Kustas, W. P.: Use of Landsat thermal imagery in monitoring evapotranspiration and managing water resources, Remote Sens. Environ., 122, 50-65, 2012.

Baldocchi, D., Falge, E., Gu, L., Olson, R., Hollinger, D., Running, S., Anthoni, P., Bernhofer, C., Davis, K., and Evans, R.: FLUXNET: A new tool to study the temporal and spatial variability of ecosystem-scale carbon dioxide, water vapor, and energy flux densities, B. Am. Meteorol. Soc., 82, 2415-2434, 2001.

Baldocchi, D. D. and Ryu, Y.: A synthesis of forest evaporation fluxes - from days to years - as measured with eddy covariance, in: Forest Hydrology and Biogeochemistry, Springer, 101-116, 2011.

Bawazir, A. S., Luthy, R., King, J. P., Tanzy, B. F., and Solis, J.: Assessment of the crop coefficient for saltgrass under native riparian field conditions in the desert southwest, Hydrol. Process., 28, 6163-6171, doi:10.1002/Hyp.10100, 2014.

Bond-Lamberty, B. and Thomson, A.: Temperature-associated increases in the global soil respiration record, Nature, 464, 579$582,2010$.

Budyko, M.: Climate and Life, Academic Press, New York, 1974.

Consoli, S. and Vanella, D.: Mapping crop evapotranspiration by integrating vegetation indices into a soil water balance model, Agr. Water Manage., 143, 71-81, doi:10.1016/j.agwat.2014.06.012, 2014.

Descheemaeker, K., Raes, D., Allen, R., Nyssen, J., Poesen, J., Muys, B., Haile, M., and Deckers, J.: Two rapid appraisals of FAO-56 crop coefficients for semiarid natural vegetation of the northern Ethiopian highlands, J. Arid Environ., 75, 353-359, doi:10.1016/j.jaridenv.2010.12.002, 2011.

Ding, R. S., Tong, L., Li, F. S., Zhang, Y. Q., Hao, X. M., and Kang, S. Z.: Variations of crop coefficient and its influencing factors in an arid advective cropland of northwest China, Hydrol. Process., 29, 239-249, doi:10.1002/Hyp.10146, 2015.

Donohue, R. J., Roderick, M. L., and McVicar, T. R.: On the importance of including vegetation dynamics in Budyko's hydrological model, Hydrol. Earth Syst. Sci., 11, 983-995, doi:10.5194/hess11-983-2007, 2007.

Du, T., Kang, S., Zhang, J., and Davies, W. J.: Deficit irrigation and sustainable water-resource strategies in agriculture for China's food security, J. Exp. Bot., 66, 2253-2269, doi:10.1093/jxb/erv034, 2015.
Fang, Y., Sun, G., Caldwell, P., McNulty, S. G., Noormets, A., Domec, J. C., King, J., Zhang, Z., Zhang, X., and Lin, G.: Monthly land cover - evapotranspiration models derived from global eddy flux measurements and remote sensing data, Ecohydrology, 9, 248-266, doi:10.1002/eco.1629, 2015.

Fereres, E. and Soriano, M. A.: Deficit irrigation for reducing agricultural water use, J. Exp. Bot., 58, 147-159, 2007.

Hao, L., Sun, G., Liu, Y., Gao, Z., He, J., Shi, T., and Wu, B.: Effects of precipitation on grassland ecosystem restoration under grazing exclusion in Inner Mongolia, China, Landscape Ecol., 29, 16571673, doi:10.1007/s10980-014-0092-1, 2014.

Hao, L., Sun, G., Liu, Y., and Qian, H.: Integrated Modeling of Water Supply and Demand under Management Options and Climate Change Scenarios in Chifeng City, China, J. Am. Water Resour. As., 51, 655-671, 2015a.

Hao, L., Sun, G., Liu, Y., Wan, J., Qin, M., Qian, H., Liu, C., Zheng, J., John, R., Fan, P., and Chen, J.: Urbanization dramatically altered the water balances of a paddy field-dominated basin in southern China, Hydrol. Earth Syst. Sci., 19, 3319-3331, doi:10.5194/hess-19-3319-2015, 2015 b.

Hasper, T. B., Wallin, G., Lamba, S., Hall, M., Jaramillo, F., Laudon, H., Linder, S., Medhurst, J. L., Rantfors, M., Sigurdsson, B. D., and Uddling, J.: Water use by Swedish boreal forests in a changing climate, Funct. Ecol., 30, 690-699, doi:10.1111/1365-2435.12546, 2016.

Hou, L. G., Xiao, H. L., Si, J. H., Xiao, S. C., Zhou, M. X., and Yang, Y. G.: Evapotranspiration and crop coefficient of Populus euphratica Oliv forest during the growing season in the extreme arid region northwest China, Agr. Water Manage., 97, 351-356, 2010.

Irmak, S., Kabenge, I., Rudnick, D., Knezevic, S., Woodward, D., and Moravek, M.: Evapotranspiration crop coefficients for mixed riparian plant community and transpiration crop coefficients for Common reed, Cottonwood and Peach-leaf willow in the Platte River Basin, Nebraska-USA, J. Hydrol., 481, 177-190, doi:10.1016/j.jhydrol.2012.12.032, 2013a.

Irmak, S., Odhiambo, L. O., Specht, J. E., and Djaman, K.: Hourly And Daily Single And Basal Evapotranspiration Crop Coefficients as a Function Of Growing Degree Days, Days after Emergence, Leaf Area Index, Fractional Green Canopy Cover, And Plant Phenology for Soybean, T. ASABE, 56, 1785-1803, 2013b.

Jaramillo, F., Prieto, C., Lyon, S. W., and Destouni, G.: Multimethod assessment of evapotranspiration shifts due to nonirrigated agricultural development in Sweden, J. Hydrol., 484, 55-62, doi:10.1016/j.jhydrol.2013.01.010, 2013.

Jaramillo, F. and Destouni, G.: Local flow regulation and irrigation raise global human water consumption and footprint, Science, 350, 1248-1251, doi:10.1126/science.aad1010, 2015.

Jung, M., Reichstein, M., Ciais, P., Seneviratne, S. I., Sheffield, J., Goulden, M. L., Bonan, G., Cescatti, A., Chen, J., and De Jeu, R.: Recent decline in the global land evapotranspiration trend due to limited moisture supply, Nature, 467, 951-954, 2010.

Kang, S., Gu, B., Du, T., and Zhang, J.: Crop coefficient and ratio of transpiration to evapotranspiration of winter wheat and maize in a semi-humid region, Agr. Water Manage., 59, 239-254, 2003.

Kar, G., Verma, H. N., and Singh, R.: Effects of winter crop and supplemental irrigation on crop yield, water use efficiency and profitability in rainfed rice based cropping sys- 
tem of eastern India, Agr. Water Manage., 79, 280-292, doi:10.1016/j.agwat.2005.03.001, 2006.

Lu, J., Sun, G., McNulty, S. G., and Amatya, D.: A comparison of six potential evapotranspiration methods for regional use in the Southeastern United States, J. Am. Water Resour. As., 41, 621633, 2005

Marsal, J., Casadesus, J., Lopez, G., Girona, J., and Stöckle, C.: Disagreement between tree size and crop coefficient in "conference" pear: comparing measurements by a weighing Lysimeter and prediction by Cropsyst, Acta Hortic., 1038, 303-310, doi:10.17660/ActaHortic.2014.1038.36, 2014a.

Marsal, J., Johnson, S., Casadesus, J., Lopez, G., Girona, J., and Stöckle, C.: Fraction of canopy intercepted radiation relates differently with crop coefficient depending on the season and the fruit tree species, Agr. Forest Meteorol., 184, 1-11, doi:10.1016/j.agrformet.2013.08.008, 2014b.

Mu, Q., Zhao, M., Kimball, J., McDowell, N., and Running, S.: A remotely sensed global terrestrial drought severity index, in: Evapotranspiration in the Soil-plant-atmosphere System, AGU Fall Meeting Abstracts, L02, 2012.

Novák, V.: Evapotranspiration in the Soil-plant-atmosphere System, Springer Science \& Business Media, 2012.

Parent, A. C. and Anctil, F.: Quantifying evapotranspiration of a rainfed potato crop in South-eastern Canada using eddy covariance techniques, Agr. Water Manage., 113, 45-56, doi:10.1016/j.agwat.2012.06.014, 2012.

Pereira, L. S., Allen, R. G., Smith, M., and Raes, D.: Crop evapotranspiration estimation with FAO56: Past and future, Agr. Water Manage., 147, 4-20, 2015.

Potter, C. S., Randerson, J. T., Field, C. B., Matson, P. A., Vitousek, P. M., Mooney, H. A., and Klooster, S. A.: Terrestrial ecosystem production: a process model based on global satellite and surface data, Global Biogeochem. Cy., 7, 811-841, 1993.

Rao, L., Sun, G., Ford, C., and Vose, J.: Modeling potential evapotranspiration of two forested watersheds in the southern Appalachians, T. ASABE, 54, 2067-2078, 2011.

Shukla, S., Shrestha, N. K., and Goswami, D.: Evapotranspiration And Crop Coefficients for Seepage-Irrigated Watermelon with Plastic Mulch In a Sub-Tropical Region, T. ASABE, 57, 10171028, 2014a.

Shukla, S., Shrestha, N. K., Jaber, F. H., Srivastava, S., Obreza, T. A., and Boman, B. J.: Evapotranspiration and crop coefficient for watermelon grown under plastic mulched conditions in sub-tropical Florida, Agr. Water Manage., 132, 1-9, doi:10.1016/j.agwat.2013.09.019, 2014b.

Stephenson, N.: Actual evapotranspiration and deficit: biologically meaningful correlates of vegetation distribution across spatial scales, J. Biogeogr., 25, 855-870, 1998.

Sun, G., Noormets, A., Gavazzi, M. J., McNulty, S. G., Chen, J., Domec, J. C., King, J. S., Amatya, D. M., and Skaggs, R. W.: Energy and water balance of two contrasting loblolly pine plantations on the lower coastal plain of North Carolina, USA, Forest Ecol. Manag., 259, 1299-1310, doi:10.1016/j.foreco.2009.09.016, 2010.

Sun, G., Alstad, K., Chen, J. Q., Chen, S. P., Ford, C. R., Lin, G. H., Liu, C. F., Lu, N., McNulty, S. G., Miao, H. X., Noormets, A., Vose, J. M., Wilske, B., Zeppel, M., Zhang, Y., and Zhang, Z. Q.: A general predictive model for estimating monthly ecosystem evapotranspiration, Ecohydrology, 4, 245255, doi:10.1002/Eco.194, 2011a.

Sun, G., Caldwell, P., Noormets, A., McNulty, S. G., Cohen, E., Moore Myers, J., Domec, J. C., Treasure, E., Mu, Q., and Xiao, J.: Upscaling key ecosystem functions across the conterminous United States by a water - ecosystem model, J. Geophys. Res. Biogeo., 116, G00J05, doi:10.1029/2010JG001573, 2011b.

Sun, S., Chen, H., Ju, W., Yu, M., Hua, W., and Yin, Y.: On the attribution of the changing hydrological cycle in Poyang Lake Basin, China, J. Hydrol., 514, 214-225, 2014.

Sun, S., Sun, G., Caldwell, P., McNulty, S., Cohen, E., Xiao, J., and Zhang, Y.: Drought impacts on ecosystem functions of the US National Forests and Grasslands: Part II assessment results and management implications, Forest Ecol. Manag., 353, 269-279, 2015a.

Sun, S., Sun, G., Caldwell, P., McNulty, S. G., Cohen, E., Xiao, J., and Zhang, Y.: Drought impacts on ecosystem functions of the US National Forests and Grasslands: Part I evaluation of a water and carbon balance model, Forest Ecol. Manag., 353, 260-268, $2015 b$.

Tabari, H., Grismer, M. E., and Trajkovic, S.: Comparative analysis of 31 reference evapotranspiration methods under humid conditions, Irrigation Sci., 31, 107-117, 2013.

Taylor, N., Mahohoma, W., Vahrmeijer, J., Gush, M., Allen, R. G., and Annandale, J. G.: Crop coefficient approaches based on fixed estimates of leaf resistance are not appropriate for estimating water use of citrus, Irrigation Sci., 33, 153-166, 2015.

Tolk, J. A. and Howell, T. A.: Measured and simulated evapotranspiration of grain sorghum grown with full and limited irrigation in three high plains soils, T. ASAE, 44, 1553-1558, 2001.

Vose, J. M., Sun, G., Ford, C. R., Bredemeier, M., Otsuki, K., Wei, X., Zhang, Z., and Zhang, L.: Forest ecohydrological research in the 21 st century: what are the critical needs?, Ecohydrology, 4, 146-158, 2011.

Wei, Z., Paredes, P., Liu, Y., Chi, W. W., and Pereira, L. S.: Modelling transpiration, soil evaporation and yield prediction of soybean in North China Plain, Agr. Water Manage., 147, 43-53, doi:10.1016/j.agwat.2014.05.004, 2015.

Xiao, J., Ollinger, S. V., Frolking, S., Hurtt, G. C., Hollinger, D. Y., Davis, K. J., Pan, Y., Zhang, X., Deng, F., and Chen, J.: Datadriven diagnostics of terrestrial carbon dynamics over North America, Agr. Forest Meteorol., 197, 142-157, 2014.

Zeppel, M. J. B., Macinnis-Ng, C. M. O., Yunusa, I. A. M., Whitley, R. J., and Earnus, D.: Long term trends of stand transpiration in a remnant forest during wet and dry years, J. Hydrol., 349, 200213, doi:10.1016/j.jhydrol.2007.11.001, 2008.

Zhang, B., Liu, Y., Xu, D., Zhao, N., Lei, B., Rosa, R. D., Paredes, P., Paço, T. A., and Pereira, L. S.: The dual crop coefficient approach to estimate and partitioning evapotranspiration of the winter wheat-summer maize crop sequence in North China Plain, Irrigation Sci., 31, 1303-1316, 2013.

Zhang, F., Zhou, G. S., Wang, Y., Yang, F. L., and Nilsson, C.: Evapotranspiration and crop coefficient for a temperate desert steppe ecosystem using eddy covariance in Inner Mongolia, China, Hydrol. Process., 26, 379-386, 2012.

Zhang, L., Dawes, W. R., and Walker, G. R.: Response of mean annual evapotranspiration to vegetation changes at catchment scale, Water Resour. Res., 37, 701-708, 2001. 
Zhang, Y., Song, C., Sun, G., Band, L. E., McNulty, S., Noormets, A., Zhang, Q., and Zhang, Z.: Development of a coupled carbon and water model for estimating global gross primary productivity and evapotranspiration based on eddy flux and remote sensing data, Agr. Forest Meteorol., 223, 116-131, 2016.
Zhou, L., Zhou, G. S., Liu, S. H., and Sui, X. H.: Seasonal contribution and interannual variation of evapotranspiration over a reed marsh (Phragmites australis) in Northeast China from 3-year eddy covariance data, Hydrol. Process., 24, 1039-1047, 2010. 